$6 \mathrm{ml}$. I.P. of the precipitated antigen suspension on approximately six successive days. In some cases the rabbits also received additional doses of native serum and were bled $2-3$ weeks later if the titres were satisfactory

(2) An alum-precipitated antigen prepared by the method of Proom ${ }^{4}$ was also used. The rabbits receiving this antigen were injected with $10 \mathrm{ml}$. I.M. into both hind legs, and were finally bled approximately three weeks later.

Both methods of immunization gave satisfactory precipitating sera, and these were used in the tests reported below. The antisera on testing mostly gave positive precipitin ring tests with the homologous test serum when the latter was used at dilutions of $1 / 3,000-1 / 20,000$. However, none of the rabbit anti-sera used by me when tested with $R h$ sensitized cells, after absorption with $A, B$ and $O$ cells, gave titres as good as those reported by Coombs et al.

The rabbit anti-sera which had been prepared during 1943-44 contained 0.02 per cent 'Merthiolate' as a preservative and had been Seitz-filtered through E.K. pads, ampouled and stored at $5^{\circ} \mathrm{C}$.

Results. The celis employed in the following tests were the washed red cells of a baby of Group $O$ sensitized in vivo; normal cells of Group $O$; cells of Group $A$ sensitized in vitro with a human serum of Group ' $A$ containing pure anti- $R h_{0}\left(\triangle^{\prime}\right)$ 'blocking' or 'incomplete' antibody ; normal cells of Group $A$, and normal cells of Group $B$. Some rabbit anti-sera tested were first absorbed with $A, B$ and $O$ cells, and others were used diluted beyond the range of hetero-agglutination which, in most cases, did not extend beyond a dilution of $1 / 5$. With some animal anti-sera heteroagglutination was seen only in the With some animal anti-sera heteroagglutination was serum and then was extremely weak.

The following precipitating anti-sera prepared in rabbits gave The following precipitating anti-sera prepared in rabbits gave
positive results with $R h$ sensitized cells, and hegative results with positive result

$\begin{array}{ll}\text { Rabbit anti-human } & \text { (2 lots) } \\ \text { Rabbit anti-porcine (pig) } & \text { (2 lots) } \\ \text { Rabbit anti-feline (cat) } & \text { (1 lot) } \\ \text { Rabbit anti-equine (horse) } & \text { (1 lot) } \\ \text { Rabbit anti-caprine (goat) } & \text { (2 lots) } \\ \text { Rabbit anti-canine (dog) } & \text { (1 lot) } \\ \text { Rabbit anti-bovine (ox) } & \text { (1 lot) }\end{array}$

Negative results with $R h$ sensitized cells were obtained with rabbit anti-galline (fowl) (3 lots). Two of these anti-sera showed no evidence of hetero-agglutinins for normal $A, B$ and $O$ cells, while the other, prepared by the alum-precipitated method, showed the presence of a further check showed that they had not deteriorated as precipitating sera on storage for over two years at $5^{\circ} \mathrm{C}$.

The above results are reported because they are interesting, and because data of this kind may help to throw further light on the immunological basis of the test described by Coombs, Mourant and immunological basis of the test described by Coombs, Mourant and
Race. The test is one which promises to have wide applications and Race. The test is one which promises to have wide applications and
general use. It should be noted that Coombs et al. have shown that general use. It should be noted that Coombs et al. have shown that the test is not confined to $R$ h sensitization, but has been the means of detecting a new antigen and antibody. The test to date has been found to give negative results when the baby has hæmolytic disease
due to blood group agglutinins anti- $A$ or anti- $B$, and the reason for this has not yet been proved.

The Commonwealth Serum Laboratories,

R. T. Srmons

Melbourne, N.

Aug. 16 .

${ }^{1}$ Coombs, R. R. A., Mourant, A. E., and Race, R. R., Lancet, ii, 15

' Coombs, R. R. A., Mourant, A. E., and Race, R. R., Brit. J. Exp. Path., 26, 255 (1945).

${ }^{3}$ Coombs, R. R. A., Mourant, A. E., and Race, R. R., Lancet, i, 264

'Proom, H., J. Path. Bact., 55, 419 (1943).

The Incomplete Antibody: a Quantitative Aspect

Ir is widely believed that the titre of the incomplete or blocking $\left(\Delta^{\prime}\right)$ antibody, as determined by the quantitative 'saline test' ${ }^{\prime}$, is dependent on the dilution of the anti- $R h_{0}(\Delta)$ serum added to the dependent on the dilution of the anti- $R h_{0}(\Delta)$ serum added to the
mixture of red cells and unknown serum ${ }^{2}$. Coombs, Mourant and mixture of red cells and unknown serum ${ }^{2}$. Coombs, Mourant and, effect at this time still remained proof against our strongest $\triangle$ serum". However, if the incomplete antibody is 'univalent', as suggested by However, if the incomplete antibody is 'univalent', as suggested by Wiener', and if the 'blocking' effect is a quantitative reaction, the expected to be dependent on the absolute amount of incomplete antibody $\left(\Delta^{\prime}\right)$ present and not on the amount of the anti- $R h_{0}(\Delta)$ serum

The results of the 'saline tests' with various dilutions of serum containing the anti- $R h_{0}(\Delta)$ serum provide some information of the nature of the reaction.

The serum containing incomplete antibody $\left(\Delta^{\prime}\right)$ was serially diluted with saline and to each dilution was added an equal volume of a 1 per cent suspension of $R h_{0}(c D e)$ red cells. The mixtures, which were made in small test tubes, were incubated at $37^{\circ} \mathrm{C}$. for thirty minutes. A volume (equal to that already contained in the tube) of serum containing the anti- $R h_{0}(\triangle)$ agglutinin in high titre was then added to each tube, and the tubes incubated for a further sixty minutes. was carefully removed from each tube with a fine capillary pipette and placed on a microscope slide. The cells were examined under por tion. The titre of the incomplete antibody $\left(\Delta^{\prime}\right)$ was taken to be the last dilution of the unknown serum in which agglutination was absent. Four different sera containing an incomplete antibody $\left(\Delta^{\prime}\right)$ were tested against various dilntions of the anti-R $h_{v}(\Delta)$, and all gave consistent results. A typical protocol is shown in the accompanying table.

\begin{tabular}{|c|c|c|c|c|c|}
\hline \multirow[b]{2}{*}{$\begin{array}{l}\text { Dilution of anti- } \\
R h_{0}(\Delta) \text { serum }\end{array}$} & \multicolumn{5}{|c|}{$\begin{array}{c}\text { Dilution of serum containing incomplete } \\
\text { antibody }\left(\Delta^{\prime}\right)\end{array}$} \\
\hline & $1 / 2$ & $1 / 4$ & $1 / 8$ & $1 / 32$ & $1 / 128$ \\
\hline $\begin{array}{l}1 / 2 \\
1 / 4 \\
1 / 8 \\
1 / 10 \\
1 / 20\end{array}$ & $\begin{array}{l}\bar{z} \\
\bar{z}\end{array}$ & $\begin{array}{l}= \\
= \\
=\end{array}$ & $\begin{array}{l}+ \\
+ \\
+ \\
+\end{array}$ & $\begin{array}{l}+ \\
+ \\
+ \\
+\end{array}$ & $\begin{array}{l}+ \\
+ \\
+ \\
+ \\
+\end{array}$ \\
\hline
\end{tabular}

The titre of the incomplete antibody $\left(\Delta^{\prime}\right)$ in the other three sera was similarly independent of the dilution of the serum containing anti- $R h_{0}(\triangle)$ agglutination.

The results are consistent with the concept that there is a common receptor on the surface of the $R h$-positive red cell for anti- $R h_{0}(\Delta)$ agglutinin and the incomplete antibody $\left(\Delta^{\prime}\right)$. If the incomplete ant body $\left(\Delta^{\prime}\right)$ forms a union with all these receptors then even large amounts of tho anti- $R h_{0}(\Delta)$ sernm will not produce agglutination On the other hand, if the amount of the incomplete antibody ( $\Delta^{\prime}$ ) present is insufficient to unite with all the receptors, added antid $h_{0}(\Delta)$ serum will unite with the remaining receptors and produce aggiutination of the red cells. However, although the results are consistent with this quantitative concept, they do not necessarily provide confirmation of this theory.

N.S.W. Red Cross Blood Transfusion Service, Sydney.
Aug. 24 .

1 de Burgh, P. M., Sanger, Ruth A., and Walsh, R. J., in the press. ${ }^{2}$ Henry, N. R., and Simmons, R. T., personal communications. s Coombs, R. R. A., Mourant, A. E., and Race, R. R., Lancet, i, 264 (1946). A. S., Proc. Soc. Exp. Biol, and Med., 51, 173 (1944).

\section{Testicle and Spermatic Tract Lesions in Lymphogranuloma Venereum}

IN a report on venereal diseases in West Africa by Lieut.-Colonel R. R. Willcox ${ }^{1}$, when referring to other tropical conditions, he says : "Hydrocoles are very common in the African though considering the amount of gonorrhœa it is not surprising". According to him, lymphogranuloma venereum (inguinale) is also very common among these atives.

L.V. is responsible for a certain number of cases of epididymal inflammations, many of them of a subclinical type ${ }^{2-6}$, others, especially when the infection with Neisseria gonorrhœa has been simultaneous, with intense inflammatory symptoms. Some of these cases are accompanied by vaginalitis, which is rapidly reabsorbed, others follow a different course and hydroccle is installed. Both subclinical or associated L.V.-gonorrhœea cases may follow a slow course and occasionally small epididymal abscesses adhere to the scrotum, break down and leave draining sinuses that heal spontaneously or under treatment. In all mentioned types, L.V. infection is seldom suspected ${ }^{2}$.

In some cases the process mainly affects the blood-vessels and lymphatics of the spermatic cord; the vas or ductus deferens remaining normal or slightly enlarged. Thrombo-angiitis, phlebitis and lymphangiitis with micro-abscess formation can be found on study of sections of these structures.

Lesions of L.V. nature of the testicle proper have also been recorded ${ }^{8,9}$.

Our observations have all been made in a country where filariasis is unknown.

Department for Social Hygiene,

National Service of Health,

${ }^{1}$ Willeox, R. R., Nature, 157, 416 (1946).

2 Coutts and Vargas Zalazar, Ann. Malad. Venér., 31, 895 (1936).

Sato Akira, Japan. J Dermat. and Urol., 39, 75 (1936)

s Bizzozero and Franchi, Minerva Med., 2, 241 (1937).

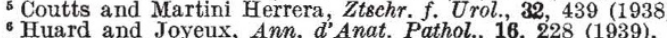

7 Coutts, Brit.J.Ven. Dis. 19,37 (1943).

8 Bastos de Sequeira, Bol.' Soc. Med. e Cir. de Sao Paulo, 26, 13 (1942)

- Midana, Dermatologica, 85, 403 (1942).

DR. CoCTTS's letter is very interesting as the writer has made a particular study of intra-urethral infections of lymphogranuloma venereum (inguinale).

As regards hydrocoles in West Africa, however, the matter of their origin is difficult to determine. Gonorrhoa is extremely prevalen there and, apart from lymphogranuloma venereum, which is also very common, there are also filariasis, dracontiasis and schistosomiasis, as well as other genito-urinary conditions, which may subscribe to their production.

As a basis of probability, gonorrhœa is singled out as the most likely antecedent while the other diseases mentioned are probably more common causes than the comparatively rare one of lymphogranuloma venereum. This matter is very hard to prove as a hydrocole in a patient showing a positive Frei test is by no means proof that the hydroccle is due to lymphogranuloma venereum, as the Frei test may remain positive for a very long time after infection.

Military Isolation Hospital, R. R. WInLCOX 